\title{
Factors Impacting Technology Business Incubator Performance
}

\author{
Muhammad Binsawad \\ Faculty of Engineering and IT \\ University of Technology Sydney \\ Sydney, Australia \\ Osama Sohaib \\ Faculty of Engineering and IT \\ University of Technology Sydney \\ Sydney, Australia \\ Igor Hawryszkiewycz \\ Faculty of Engineering and IT \\ University of Technology Sydney \\ Sydney, Australia
}

\author{
Muhammad.Binsawad@student.uts.edu.au
}

\author{
Osama.Sohaib@uts.edu.au
}

Igor.Hawryszkiewycz@uts.edu.au

\begin{abstract}
Technology business incubators support economic growth by developing innovative technologies. However, assessing the performance of technology business incubators in Saudi Arabia has not well recognized. This study provides a conceptual framework for assessing technology business incubators based on knowledge sharing practices and sharing, diffusion of innovation and individual creativity. Partial least squares structural equation modelling, such as (PLS-SEM) path modelling was used to test the model. The results provide empirical insights about the performance of technology business incubators. The findings show knowledge donation and collection has positive effects on technology business incubator. The importance-performance map analysis shows additional findings and conclusions for managerial actions.
\end{abstract}

Keywords: Technology incubator, Business incubator, Knowledge sharing, diffusion of innovation, Creativity, Saudi Arabia

\section{Introduction}

The main purpose of technology business incubation is supporting innovation through joint cooperation between competences and resources. As noted by Yee (2009), "The technology incubator is an entity where knowledge is transformed into innovative products and services (Yee 2009)." The combination of knowledge-sharing and incubator management helps these incubators to produce successful projects. Cheng and Schaeffer (2011) found that business incubator functions had a positive impact on the economy in the 1980s. However, some issues were identified with the standard accepted for this examination. A review of the literature shows the impact of business incubators was examined for different categories: job creation (Udell 1990), incubatee development (Smilor 1987) and 
incubatee graduation percentages (Peters et al. 2004). The incubators reviewed were of diverse types, including as university-linked incubators, non-profit incubators and for-profit incubators (Peters et al. 2004). A company's knowledge base is the essential factor of the growth of the company and its competition with other companies (Gupta and Govindarajan 2000). One of the principal challenges in is creating projects using what incubators produce or incorporating incubators in new projects. To ensure the success of new projects, many sources are required (Brush and Greene 1996). Good performance, the sustainability of the projects and acquaintance are critical factors. Because of the growth of a knowledge-based economy, technology and innovation are considered as important components of performance (Rooney et al. 2012). The business economy that can be enhanced by business organizations relies on their ability to innovate. Therefore, a lack of ability to do this blocks them of completion and limits their business development and ability to improve their profits (Taylor et al. 1993). Innovation can contribute to rises in productivity, a high level of competition and wealth generation (Carlson and Wilmot 2006).

There are two areas in the literature on business incubation: industry based and academic based. Incubation is treated as an agency emphasizing on the relation between knowledge and innovation. Many technology incubators are linked with study organizations such as universities, tech-parks or corporate/industries with research and development (R\&D) resources in public and private sectors (Ascigil and Magner 2009; Hughes et al. 2007; Tötterman and Sten 2005). As a result, technology incubators are contributing to supporting entrepreneurs, tech-based organizations and other affiliates of universities and big organizations by providing appropriate materials for survival, wealthgeneration and job foundation.

In the Kingdom of Saudi Arabia, incubators are considered an essential part of the technological development of the country by encouraging business innovation. The main goal of Saudi incubators is to help Saudi society become more knowledge based, leading to the development of a knowledgebased economy through designed programs providing good opportunities to help in such situation. A review of related studies shows that technology incubation in KSA is in its progress levels (Khorsheed et al. 2012). In the cities of Riyadh and Jeddah, there are two private-sector firms that operate as technology incubators by providing fee-based services to aspiring entrepreneurs. Saudi technology incubators are not autonomous institutions because they work under universities. Therefore the funding and services provided in these incubators are limited (Salem 2014). Saudi Arabia has also moved in with the rest of the world to develop technology incubators, although they are at the preliminary stages of introducing technology and science parks mostly. It has been noted in research that in the developing countries, including the Saudi Arabia, technology incubators have not been able to come up to their expectations. They have not been contributing to the development of local economy, the transfer of technology, creation of new enterprises, and increase of job creation (AlMubaraki et al., 2010). Most of the Arab world faces deficiencies in their infrastructure as also in their products and services like goods, labor and their financial markets and slow pace of innovations 
and technological up-gradation; this is brought out in the 2010-2011 World Economics Forum's Global Competitiveness report (Schwab and Sala-i-Martin, 2010). Better resources and services enable entrepreneurs and startups to achieve higher growth and development facilitated by business incubation. There is no sound foundation theoretically to the available knowledge of the process of business incubation (Tamasy, 2007). Therefore, the inferences concerning business incubations and the effect they have on startups are not consolidated or clear (Chan and Lau, 2005). The aim of business is to support successful startups. That knowledge is the vital determining factor for developing successful startups is a widely acknowledged fact. A new venture's performance is dependent on the knowledge that it is able to acquire as per many academic scholars (Studdard 2006, Wiklund and Shepherd 2003, West and Noel 2009).

There is a lack of existing knowledge about the process of business incubation (Tamasy 2007). Consequently, the effect of business incubation and the influence incubators have on startups are not confirmed or clear (Chan and Lau 2005). The goal of business incubators is to help new companies become established and successful. It has been proven that knowledge plays a fundamental role in successful startups. The knowledge is significant for a new projects' performance (West and Noel 2009). This research extends (Binsawad et al. 2017) previous research to examine how the performance of Saudi technology business incubators are affected by applying knowledge-sharing practices, individual creativity, and diffusion of innovation. The research question has been formulated to investigate the research gaps that are related to the current study. What are the factors influencing knowledge-sharing process (donation and collection) and technology business incubator in Saudi context?

The paper is organized as follows. The following section 2 presents theoretical development and research model, and then the hypotheses development. Section 3 discusses the methodology followed by data analysis in section 4 . Section 5 discusses the implications and finally the study concludes.

\section{Theoretical Background and Research Model}

This study attempts to identify the influence of knowledge sharing process, individual creativity and diffusion of innovation toward technology business incubators performance in Saudi Arabia. Hence, the theoretical foundations include existing models related to knowledge-sharing, diffusion of innovation (DOI) theory and individual creativity towards organization performance. Figure 1 shows the research model and Table 1 presents a description of each factor.

There are various types of incubators, such as business and technology. Business incubators are meant to develop and stimulate general businesses for specific economic objectives like industrial restructuring and the generation of revenue as well as the beneficial utilization of available resources (Bollingtoft and Ulhoi 2005). Technology incubators aim to bolster the technology development stage 
of enterprises and new businesses being promoted by business incubators (Smilor 1987). The first technology incubator to be established in the Saudi Arabia was BADIR-ICT, which was launched in January 2008 (Al-Mubaraki et al. 2010). As the first incubator to become operational within a short time, this incubator started to accept its initial projects while working as a part of the National Badir Technology Incubator Initiative of Saudi Arabia's national research institute at the King Abdul Aziz City for Science and Technology.

Knowledge donation and knowledge collection are the two knowledge-sharing processes (Lin 2007; Van Den Hooff and De Ridder 2004).These terms illustrate the process where knowledge is exchanged, transmit and created between staff. The literature review shows the influences of knowledge-sharing are categorized into two groups: individual influences and organizational influences (Connelly and Kevin Kelloway 2003; Lee and Choi 2003). In knowledge-sharing individual extent, the majority of related literature studied the individual influences of self-efficacy (Lin 2007; Wasko and Faraj 2005), enjoyment in sharing knowledge (Lin 2007), and interpersonal trust (Bijlsma and Koopman 2003; Davenport and Prusak 1998; Fukuyama 1995; Ma et al. 2008). Also, looking at organizational knowledge-sharing organizational, the majority of related literature discussed motivational influences that consist of management support (Artail 2006; Riege 2005; Song 2009; Yew Wong 2005), information technology infrastructure (De Vries et al. 2006; Hsu 2008), and inducements and rewards (Bartol and Srivastava 2002; Davenport and Prusak 1998; Yew Wong 2005). To consider the impact of the individual (self-efficacy and enjoyment), organizational (top management support, organization rewards) and technology factors (the use of IT) on the knowledgesharing practices regarding am organization's innovation capability, as developed in Lin's a model (Lin 2007). The results show that organizations can enhance their innovation performance through developing a knowledge-sharing culture. Choi and Lee (2003) developed a model to examine the relationship between knowledge practices and enablers (such as organizational content and technological content) on organizational creativity and performance (Lee and Choi 2003). Moreover, the relation between knowledge-sharing, innovation, and organizational performance was investigated by (Wang and Wang 2012). Their findings show that financial and operational performance is affected by innovation speed and knowledge-sharing.

Incubation has been recognized as a part of the creative process. For-example, incubation process results were highlighted in novel and useful ideas through unconscious recombination of thought elements that were stimulated through conscious work (Amabile et al. 2005). "Creativity is generally defined as the production of novel, useful ideas or problem solutions. It refers to both the process of idea generation or problem solving and the actual idea or solution." (Amabile 1997). Hence, creativity refers to the implementation of creative ideas in an incubator context. Creativity is both a desired outcome of an incubator, in the sense of creating more creative and innovative firms, and a part of the 
process because creativity is required to both develop the new ideas and determine how they are best applied (Patton 2014).

Previous studies highlight a range of conditions required for fostering individual creativity in general (Woodman et al. 1993b). Indeed, there is no current consensus on the most valid and reliable way of measuring individual creativity as of the time of this study, with most scholars choosing to take one of two positions (Park et al. 2016). However, at an individual level, (Amabile 1997) extensive body of research suggests three major factors for the individual creativity of employees within organizations: Such as, expertise, creative thinking skill, and intrinsic task motivation (Amabile 1997; Amabile et al. 2005). Thus, Amabile's individual creativity, comprised of the three factors of expertise, creative thinking skill, and intrinsic task motivation is adopted in this study (Amabile 1997). Since one of the roles of technology business incubators is to prompt greater innovation in a new industry (Mian 1997), individual creativity is a highly relevant factor in understanding how technology business incubators perform, and the theory of individual creativity underpins the study.

Innovation has been widely considered as a factor in a firm's business performance. Diffusion of innovation theory denotes various dimensions that can be used to analyses the characteristics of new phenomena in the organisation (Rogers, 2003). Diffusion of Innovation theory suggests five perceived innovation characteristics: relative advantage, compatibility, complexity, observability, and trialability. In the context of this study, relative advantage, compatibility, and complexity are used because they are considered as the most significant constructs in relationship to incubator performance.

Regarding the technology business incubator performance, there is no defined and single explained standard to measure incubator performance (Phan et al. 2005). There are several studies that have discussed different indicators to determine incubator performance (M'Chirgui 2012). For example, Rothaermel and Thursby (2005) examined the university based incubators by the performance of tenant, revenues generated, total funds raised, venture capital funding obtained and whether the firm graduated, failed, or stayed in the incubator (Rothaermel and Thursby 2005). This approach focused on success as defined in terms of how well the resulting businesses performed, a valid approach but not necessarily the ideal one. In general, although incubated firms are significantly more likely to succeed than non-incubated firms (Somsuk and Laosirihongthong 2014), the likelihood of failure remains high .

Therefore, rather than taking a firm-based approach to assessing the performance of a technology business incubator, a notion more firmly grounded in the program itself would seem more appropriate. In the vein of this, Mian (1997) defines four categories of performance outcomes for the university technology business incubator, which are (a) the program sustainability and growth, (b) tenant firm's survival and growth, and (c) contributions to the sponsoring university's mission, (d) community- 
related impacts. This approach is more holistic. Since the success or failure of incubated firms does somewhat reflect on the quality of the incubator (Tang et al. 2013), this factor is an appropriate part of defining performance. Success may be the overall goal of the incubated firms, but their success only partially reflects on the incubator program and is also only part of its own mission. However, the incubator is ultimately a part of the university running it (Wonglimpiyarat 2016). Therefore, it is appropriate that assessing its performance should consider a factor representing how the incubator program actually helps the host university. Additionally, since there is a strong emphasis on using local research innovations to develop local businesses in an incubation program (Mian 1997), it is also appropriate that a holistic measure of incubator performance should include a factor assessing how the program affects the community at large. If the incubator program failed to provide a positive impact on the local community, or created businesses with a detrimental effect on that community, this should be reflected in evaluating its performance. Finally, since establishing the incubator represents an investment on the part of the university, and requires that the program is maintained and expanded as needed (Patton 2014), the sustainability and growth factor is also an important part of understanding success. No matter how successful the incubated firms may be, it would be hard to consider an unsustainable incubation program a success.

Thus, giving due consideration to the literature supporting all of these factors, the researcher decided that a holistic approach to assessing incubator performance was the most appropriate for the study. Accordingly, in the context of the current study, the researcher used Mian's assessments of incubators performance (Mian 1996; Mian 1997). 


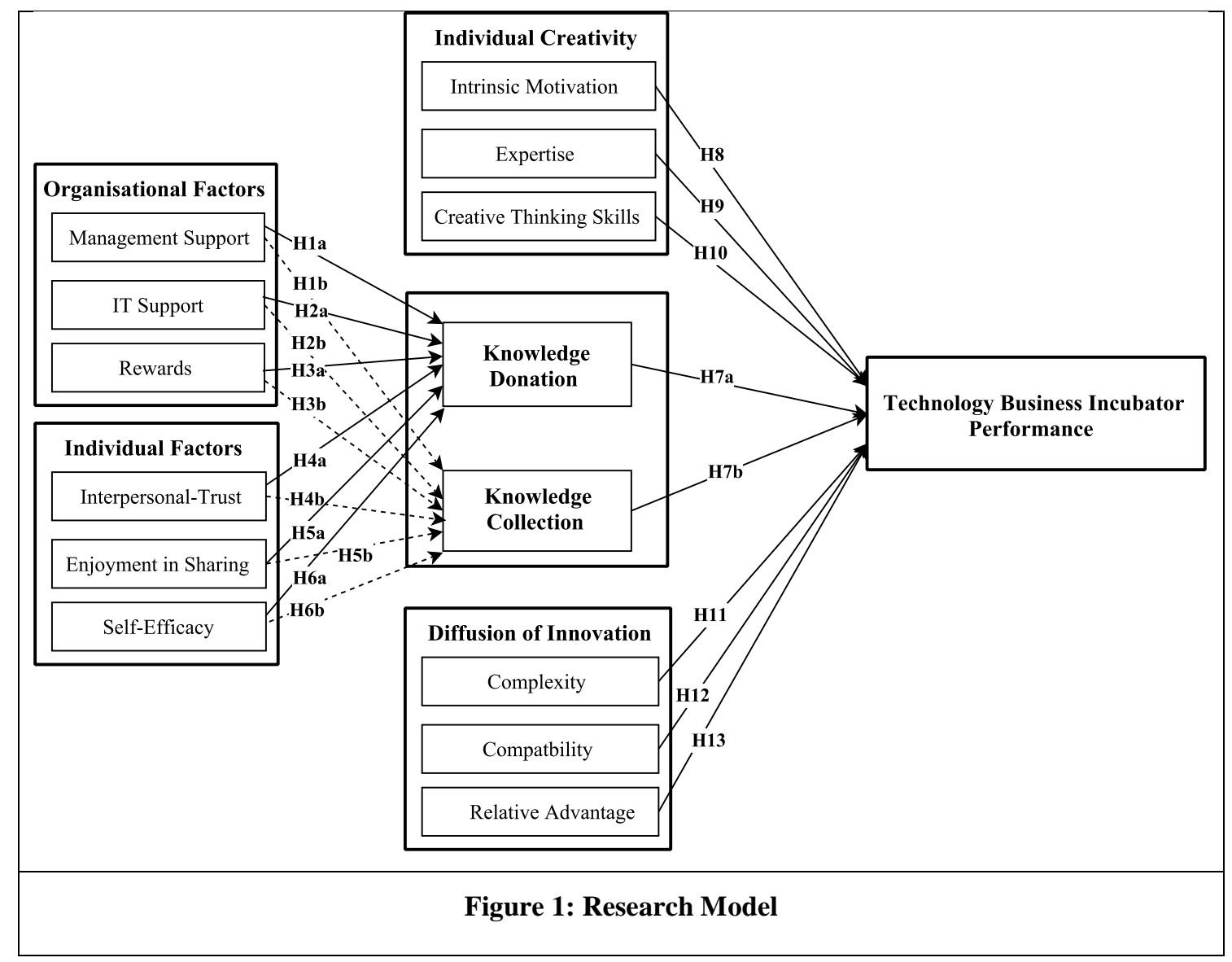

Table 1: Factor's Description

\begin{tabular}{|c|c|c|}
\hline Factor & Description & Source \\
\hline $\begin{array}{l}\text { Knowledge } \\
\text { sharing } \\
\text { process }\end{array}$ & $\begin{array}{l}\text { Knowledge donating is defined as "the process of } \\
\text { individuals communicating their personal intellectual } \\
\text { capital to others" while } \\
\text { Knowledge collecting is defined as the "process of } \\
\text { consulting colleagues to encourage them to share their } \\
\text { intellectual capital." }\end{array}$ & $\begin{array}{l}\text { (Van Den Hooff } \\
\text { and Van Weenan, } \\
\text { 2004; Lin, 2007). }\end{array}$ \\
\hline $\begin{array}{l}\text { Knowledge } \\
\text { sharing } \\
\text { individual } \\
\text { factors }\end{array}$ & $\begin{array}{l}\text { Self-efficacy is defined as the "judgments of individuals } \\
\text { regarding their capabilities to organize and execute } \\
\text { courses of action required to achieve specific levels of } \\
\text { performance." } \\
\text { Trust: refers to "co-workers having a good level of } \\
\text { faith in each other in terms of intentions and behaviors." } \\
\text { Enjoyment in sharing: refers to pleasure and joy in } \\
\text { exchange of information among people }\end{array}$ & $\begin{array}{l}\text { (Lin, 2007; } \\
\text { (Whitener 2001, } \\
\text { Politis 2003). }\end{array}$ \\
\hline $\begin{array}{l}\text { Knowledge } \\
\text { sharing } \\
\text { organizational } \\
\text { factors }\end{array}$ & $\begin{array}{l}\text { Management Support: "The degree to which the top } \\
\text { management support the organizational climate of } \\
\text { knowledge-sharing by providing sufficient resources } \\
\text { and influencing the employee willingness to share } \\
\text { knowledge." } \\
\text { IT support: refers to the "level to which facilitating } \\
\text { knowledge-sharing through information technology } \\
\text { use." }\end{array}$ & $\begin{array}{l}\text { (Lin 2007; Van den } \\
\text { Hooff and de } \\
\text { Leeuw van } \\
\text { Weenen 2004) }\end{array}$ \\
\hline
\end{tabular}




\begin{tabular}{|c|c|c|}
\hline & $\begin{array}{l}\text { Rewards: refers to "the degree to which a reward } \\
\text { system to share any new and creative ideas and } \\
\text { effectiveness knowledge-sharing." }\end{array}$ & \\
\hline Creativity & $\begin{array}{l}\text { Expertise: Expertise can be considered as skills of } \\
\text { performing a specific task in the most effective and } \\
\text { creative manner. } \\
\text { Creative-thinking skills: refers to the abilities or } \\
\text { capabilities for innovative, cognitive and creative } \\
\text { thoughts. } \\
\text { Motivation: refers to the passion and desire of someone } \\
\text { to work on a specific task that is interesting, challenging } \\
\text { and exciting for him. }\end{array}$ & $\begin{array}{l}\text { (Amabile 1988; } \\
\text { Amabile 1997; } \\
\text { Amabile et al. 2005; } \\
\begin{array}{l}\text { Woodman et al. } \\
\text { 1993a) }\end{array}\end{array}$ \\
\hline $\begin{array}{l}\text { Diffusion } \\
\text { Innovation }\end{array}$ & $\begin{array}{l}\text { Relative advantage: refers to the potential advantage } \\
\text { that could be achieved by users, if the innovation was } \\
\text { applied } \\
\text { Compatibility: It's about the extent to which } \\
\text { innovation is considered as stable with current values. } \\
\text { Complexity: This is how could the new idea or practice } \\
\text { be adopted easily that could be involved in the ability of } \\
\text { users, technical skills conditions and technological } \\
\text { requirements, etc. }\end{array}$ & $\begin{array}{lr}\text { Roger, } & 2003 ; \\
\text { Othman et al. 2014) } \\
\text { Rogers } & (2010) ; \\
\text { Fennell } & \text { and } \\
\text { Warnecke } & (2013) ; \\
\text { Seemann } & \text { (2003); } \\
\text { Sahin (2006) }\end{array}$ \\
\hline $\begin{array}{l}\text { Technology } \\
\text { Business } \\
\text { Incubator } \\
\text { Performance }\end{array}$ & $\begin{array}{l}\text { Performance Outcomes } \\
\text { - Program growth and sustainability (such as, growth } \\
\text { in budget, space, facilities, services, tenants, and } \\
\text { staff) } \\
\text { - Tenant firm's survival and growth (such as, sales } \\
\text { growth, employment growth) } \\
\text { - Contributions to sponsoring university's mission } \\
\text { - Community-related impacts (such as, sales, } \\
\text { revenues, taxes, exp, and graduate's employment, } \\
\text { etc.) }\end{array}$ & $\begin{array}{l}\text { (Mian 1996; Mian } \\
\text { 1997) }\end{array}$ \\
\hline
\end{tabular}

\subsection{Hypotheses Development}

\section{Motivational Factors for Knowledge-Sharing - Organizational Dimensions}

Management support: The vision of organizations is related to the involvement of leadership that is implicated in efficient usage of knowledge (Han and Anantatmula 2007). Management support is significant in enhancing the culture of knowledge-sharing (Artail 2006; Riege 2005). According to Wong, leaders are role models for demonstrating knowledge-sharing behavior in organizations (Yew Wong 2005). Moreover, leadership has an influence on the behavior of knowledge-sharing. For instance, managers need to support and monitor staff contribution in knowledge-sharing actions (De Vries et al. 2006; Song 2009). Hence, hypotheses posit that:

Hla-b: Management support positively impacts the knowledge-sharing process, a) donation b) collection in Saudi Arabian technology business incubators. 
Information technology (IT) support: In knowledge-sharing practice, information technology support is a major influence on the knowledge flows that accelerate the process of sharing knowledge (Hsu 2008).Two categories are the main components of IT infrastructure that is used to improve knowledge-sharing practices: hardware and software (De Vries et al. 2006) and increase knowledgesharing features like the range and timeliness (Ardichvili et al. 2003). For that reason, implementing technology in the organization's functions is very important, especially in knowledge-sharing. Therefore, it is encouraged that organizations provide IT sufficient training for staff (Han and Anantatmula 2007).Therefore, hypotheses posit that:

H2a-b: Information technology positively impacts knowledge-sharing process, a) donation $b$ ) collection in Saudi Arabian technology business incubators.

Rewards: It is recommended that staff who are involved knowledge-sharing practices be encouraged by having a reward system as motivation (Yew Wong 2005).Team performance could be more efficient if individuals contributed to the process of knowledge-sharing, which may also increase individual rewards expected (Bartol and Srivastava 2002).Having a reward system can encourage staff to be involved in the process of knowledge-sharing (Bock and Kim 2001). These values have an instant influence on motivation regarding knowledge-sharing between colleagues (Bartol and Srivastava 2002; Kharabsheh 2007). Accordingly, hypotheses posit that:

H3a-b: Rewards positively impacts knowledge-sharing process, a) donation b) collection in Saudi Arabian technology business incubators.

\section{Motivational Factors for Knowledge-Sharing - Individual Dimensions}

Interpersonal trust: Literature shows that staff can be more effective and collaborative in providing valuable knowledge if there is a trust between them (Bijlsma and Koopman 2003).A lack of trust can affect individuals in a negative way by making them unmotivated to share any kind of knowledge (Davenport and Prusak 1998; Ma et al. 2008).Consequently, individuals' inclination to donate or collect knowledge is enhanced by the interpersonal trust (Fukuyama 1995).Hence, hypotheses posit that:

H4a-b: Interpersonal trust positively impacts knowledge-sharing process, a) donation b) collection in Saudi Arabian technology business incubators.

Enjoyment in sharing knowledge: Research findings show that the joy that gained from when staff helps each other leads to make these staff more interested in providing knowledge (McLure Wasko and Faraj 2000; Wasko and Faraj 2005).Therefore, staff can be more effective in knowledge-sharing processes in both donating and collect (Lin 2007). Therefore, hypotheses posit that: 
H5a-b: Enjoyment in knowledge-sharing positively impacts knowledge-sharing process, a) donation b) collection in Saudi Arabian technology business incubators.

Self-efficacy: Self-efficacy is how a person judges his or her ability to arrange and perform daily life activities effectively (Lin 2007).The tendency of individuals to take actions (problem's difficulty, perseverance, task effort and expressed concern) effect on the individual's sense of self-efficacy (Bandura 1997; Gist 1987).Lin stated that an organization's performance is enhanced by the contributions of knowledge-sharing, if staff's willingness to donate and collect knowledge is boosted (Lin 2007). Hence, hypotheses posit that:

H6a-b: Self-efficacy positively impacts knowledge-sharing process, a) donation b) collection in Saudi Arabian technology business incubators.

\section{Knowledge-Sharing Process}

An organization's performance can be improved by organizational cerebral capital and the indefinable resources that are created by efficient knowledge practices (Nold 2012).For instance, two kinds of knowledge are tacit knowledge and explicit knowledge. It benefits the whole organization more when staff transfer knowledge from tacit into explicit (Erickson et al. 2003). This means that better knowledge management for organizations' assets leads to a greater chance to boost its performance in the market (Erickson et al. 2003; Rahab 2011). Hence, hypotheses posit that:

H7a-b: Incubatees' willingness to share knowledge, a) donation and b) collection positively impact Saudi Arabian technology business incubators' performance.

\section{Individual Creativity}

Studies highlighted that higher the level of each of the Amabile's individual creativity factors (Such as, expertise, creative thinking skill, and intrinsic task motivation (Amabile 1997), the higher will be the creativity within organizations: Creativity creates a superior performance (Grewal et al. 2009). Researchers have suggested that has a vital impact on organizational performance (George and Zhou 2002; Oldham and Cummings 1996).It is suggested that individual creativity be positively related to technology business incubator performance. Accordingly, the following hypotheses are developed;

H8: Intrinsic motivation positively impacts Saudi Arabian technology business incubators business performance.

H9: Expertise positively impacts Saudi Arabian technology business incubators performance.

H10: Creative thinking skills positively impact Saudi Arabian technology business incubators performance. 


\section{Diffusion of Innovation (DOI)}

Innovation is a mean for achieving and sustaining competitive advantages and business outcomes for business organizations. Panuwatwanich et al. (2008) showed diffusion of innovation has a significant effect on business performance (Panuwatwanich et al. 2008). In today business world, competing based on products and services is based on the underlying capabilities that make the products and services possible (Egbetokun et al. 2007). However, the complexity factor of diffusion of innovation may potentially stymie the diffusion, because more complex innovations are more difficult to diffuse and may be less attractive (Zhu 2014).Thus, the following hypothesis is proposed:

H11: Complexity has a significant negative impact on technology business incubators performance in Saudi technology business incubators.

However, compatibility with existing paradigms or preferences makes innovations significantly easier to diffuse, according to the literature (Zhu and Zhang 2015).Therefore, the following hypothesis is proposed:

H12: Compatibility has a significant positive impact on technology business incubators performance in Saudi technology business incubators.

Finally, the strength of the relative advantage offered by innovation is a significant predictor of the value placed upon it (Arfken et al. 2015). Thus, the following hypothesis is proposed.

H13: Relative advantage has a significant positive impact on technology business incubators performance in Saudi technology business incubators.

\section{Approach}

The data collection method of this research is survey instrument. The Survey instrument provides a numeric or quantitative trends description of population's opinions and attitudes based on studying a sample of this population (Creswell, 2003). Babbie (2013) states "surveys are particularly useful in descripting the characteristics of a large population because they make large samples feasible" (2012,p.7). The survey was provided in English and Arabic in this study. The survey questions applied closed-ended questions technique. In this technique, a small set of participants produces accurate answers. The participants are asked to select or rank answers instead of to responding to the questions or providing their expressing their opinions. In order to get a high response rate for the survey, there are some techniques were applied. First, designing the survey considered that 14 minutes as a maximum time to complete it. Second, using the procedures proposed by Sekaran (2003), such as, 
making the survey brief as much as possible and introducing the participants to the research objectives and the significance of the survey to the study by providing a cover sheet including this information.

Therefore, in this study applied the survey method to collect numerical data from participants in technology incubators in Saudi Arabia. The sample consists of employees at university incubators, including the King Abdullah Bin AbdulAziz Science Park (KASP), the King Saud University Science Park (KSSP) and the King Abdul Aziz City for Science and Technology (KACST) as well as BADIRICT, the Saudi Organization for Industrial Estates and Technology Zones (SOIETZ), and the Information Technology and Communication Complex (ITCC) technology incubators. The survey was originally developed in English and later translated into Arabic. Participants were required to fill in a questionnaire that contained closed ended questions that require responses on a five point Likert scale ( $1=$ strongly disagree to $5=$ strongly agree) is used. Appendix A shows all adopted items used in the study.

The research model is tested using Partial Least Squares-Structural Equation Modelling (PLS-SEM) statistical technique (Hair et al. 2011a; Hair et al. 2011b), which is considered to be suitable for this study. Henseler et al. (2014) provided a detailed analysis of PLS-SEM over CB-SEM. PLS-SEM is now a well-recognized analysis method in business information systems research because it does not require a large sample size, does not require normality and subsequently works without distributional assumptions and with nominal, ordinal and interval-scaled variables (Hair et al. 2014). PLS-SEM allows the researchers to concurrently evaluate structural path coefficients and measurement model parameters. In this research model, all constructs were modeled as reflective indicators because they are viewed as effects of latent variables.

The survey was sent to 170 participants, and 150 participated in the survey. After removing incomplete responses, a total of 140 responses have been used for data analysis. Data collection lasted from November 2016 to January 2017. The descriptive analysis shows that $70 \%$ of the participants were male and $30 \%$ were female. $65 \%$ were in the age of $26-35$ years, $25 \%$ participants are $36-45$ years, and $10 \%$ are above 45 years. $65 \%$ of the respondents hold master's degree; followed by $25 \%$ bachelor's degree and $10 \%$ hold a doctoral degree. $55 \%$ of participants have more than 5 years of work experience, followed by $30 \%$ between $3-5$ years. $25 \%$ of the participants have work experience of 1-3 years.

\section{Data Analysis}

We apply partial least squares structural equation modeling (PLS-SEM) to estimate our research model using SmartPLS version 3.0 (Ringle et al. 2015). PLS-SEM is particularly suitable when the model has a large number of latent variables because it does not lead to estimation problems or 
improper results (Henseler et al. 2009). Also, PLS path modeling results include latent variable scores which are required for providing diagnostic information about technology incubators performance and our attempt to execute an importance performance analysis.

\subsection{Measurement Model Analysis}

Previously validated survey instruments were used in order to ensure the measures are adequate and representative. The loadings of all items on their factors are significant $(\mathrm{p}<.01)$ and greater than 0.7 , which ensures indicator reliability. The Cronbach's alphas of the model factors range from 0.71 to 0.87. The PLS model estimation reveals that all model constructs exhibit satisfactory internal consistency. Composite reliability values range from 0.79 to 0.88 and average variance extracted (AVE) estimates range from $56 \%$ to $79 \%$. Table 2 shows constructs reliability and validity. In addition, we test the discriminant validity of the latent variables in the PLS model using the criterion of (Fornell and Larcker 1981). The AVE of each latent variable should be greater than the latent variable's highest squared correlation with any other latent variable. As we show in Table 3, each of the latent variables meets these requirements, in support of discriminant validity.

PLS method requires practically no bias when estimating data from a composite model population, regardless of whether the measurement model is reflective or formative (Sarstedt et al. 2016). Concerning Goodness-of-fit (GoF) indices for partial least squares path modelling, Henseler and Sarstedt (2013) show that goodness-of-fit index is not appropriate for model validation. 
Table 2: Construct Reliability and Validity

\begin{tabular}{|l|l|l|l|}
\hline & $\begin{array}{l}\text { Cronbach's } \\
\text { Alpha }\end{array}$ & $\begin{array}{l}\text { Composite } \\
\text { Reliability }\end{array}$ & $\begin{array}{l}\text { Average Variance } \\
\text { Extracted (AVE) }\end{array}$ \\
\hline Compatibility & 0.72 & 0.82 & 0.60 \\
\hline Complexity & 0.73 & 0.79 & 0.56 \\
\hline Creative thinking skills & 0.71 & 0.83 & 0.61 \\
\hline Enjoyment in Sharing & 0.73 & 0.84 & 0.63 \\
\hline Expertise & 0.74 & 0.84 & 0.63 \\
\hline IT support & 0.81 & 0.87 & 0.75 \\
\hline ITrust & 0.73 & 0.84 & 0.63 \\
\hline Intrinsic Motivation & 0.71 & 0.80 & 0.57 \\
\hline $\begin{array}{l}\text { Knowledge Sharing } \\
\text { Collection }\end{array}$ & 0.74 & 0.84 & 0.64 \\
\hline $\begin{array}{l}\text { Knowledge Sharing } \\
\text { Donation }\end{array}$ & 0.77 & 0.86 & 0.67 \\
\hline Management Support & 0.81 & 0.87 & 0.68 \\
\hline Relative Advantage & 0.76 & 0.79 & 0.56 \\
\hline Rewards & 0.78 & 0.81 & 0.59 \\
\hline Self-Efficacy & 0.74 & 0.84 & 0.63 \\
\hline $\begin{array}{l}\text { Tech. Incubator } \\
\text { Performance }\end{array}$ & 0.87 & 0.88 & 0.60 \\
\hline
\end{tabular}

Table 3: Discriminant Validity of Constructs

\begin{tabular}{|c|c|c|c|c|c|c|c|c|c|c|c|c|c|c|c|}
\hline & COM & ComX & CTS & EnjS & Exp & ITS & ITrust & IntM & KSC & KSD & MS & $\mathbf{R A}$ & Rew & SE & TIP \\
\hline $\begin{array}{l}\text { Compatability } \\
(\mathrm{COM})\end{array}$ & 0.77 & & & & & & & & & & & & & & \\
\hline Complexity (ComX) & 0.67 & 0.75 & & & & & & & & & & & & & \\
\hline $\begin{array}{l}\text { Creative thinking } \\
\text { skills (CTS) }\end{array}$ & 0.74 & 0.70 & 0.78 & & & & & & & & & & & & \\
\hline $\begin{array}{l}\text { Enjoyment in } \\
\text { Sharing (EnJS) }\end{array}$ & 0.79 & 0.71 & 0.81 & 0.79 & & & & & & & & & & & \\
\hline Expertise (Exp) & 0.61 & 0.53 & 0.73 & 0.61 & 0.79 & & & & & & & & & & \\
\hline IT support (ITS) & 0.76 & 0.61 & 0.63 & 0.68 & 0.59 & 0.86 & & & & & & & & & \\
\hline ITrust & 0.61 & 0.53 & 0.72 & 0.61 & 1.00 & 0.58 & 0.80 & & & & & & & & \\
\hline $\begin{array}{l}\text { Intrinsic Motivation } \\
\text { (IntM) }\end{array}$ & 0.69 & 0.64 & 0.64 & 0.70 & 0.54 & 0.77 & 0.54 & 0.76 & & & & & & & \\
\hline $\begin{array}{l}\text { Knowledge Sharing } \\
\text { Collection (KSC) }\end{array}$ & 0.63 & 0.77 & 0.64 & 0.71 & 0.65 & 0.66 & 0.65 & 0.61 & 0.80 & & & & & & \\
\hline $\begin{array}{l}\text { Knowledge Sharing } \\
\text { Donation (KSD) }\end{array}$ & 0.63 & 0.85 & 0.59 & 0.69 & 0.52 & 0.62 & 0.52 & 0.60 & 0.82 & 0.82 & & & & & \\
\hline $\begin{array}{l}\text { Management } \\
\text { Support (MS) }\end{array}$ & 0.69 & 0.69 & 0.67 & 0.72 & 0.55 & 0.64 & 0.54 & 0.67 & 0.67 & 0.64 & 0.83 & & & & \\
\hline $\begin{array}{l}\text { Relative Advantage } \\
\text { (RA) }\end{array}$ & 0.71 & 0.70 & 0.77 & 0.74 & 0.50 & 0.54 & 0.50 & 0.60 & 0.55 & 0.62 & 0.64 & 0.75 & & & \\
\hline Rewards (Rew) & 0.65 & 0.62 & 0.57 & 0.62 & 0.42 & 0.67 & 0.41 & 0.69 & 0.66 & 0.65 & 0.63 & 0.60 & 0.77 & & \\
\hline Self-Efficacy (SE) & 0.68 & 0.78 & 0.82 & 0.72 & 0.60 & 0.65 & 0.60 & 0.67 & 0.72 & 0.66 & 0.69 & 0.76 & 0.65 & 0.80 & \\
\hline $\begin{array}{l}\text { Tech. Incubator } \\
\text { Performance (TIP) }\end{array}$ & 0.75 & 0.76 & 0.73 & 0.86 & 0.63 & 0.71 & 0.62 & 0.73 & 0.79 & 0.75 & 0.89 & 0.69 & 0.68 & 0.80 & 0.77 \\
\hline
\end{tabular}




\subsection{Structural Model Testing}

In order to test the proposed hypotheses, the structural model was tested by analyzing the significance of the paths between factors using t-test calculated with the bootstrapping technique at a 5 percent significance level. We apply a nonparametric bootstrapping procedure (5000 subsamples) to evaluate the significance of the path coefficients (Henseler et al. 2009); we provide the path estimates in Figure 2. Table 4 shows the path co-efficient mean, standard deviation and t-statistics and p-value for each of the proposed hypotheses. The recommended $\mathrm{t}$-values are $\mathrm{t}>1.96$ at $\mathrm{p}\langle 0.05, \mathrm{t}>2.576$ at $\mathrm{p}<0.01, \mathrm{t}\rangle$ 3.29 at $p<0.001$ for two-tailed tests. The coefficients of the causal relationships between factors are determined by the significance of the path coefficients and the $\left(\mathrm{R}^{2}\right)$ variance of the dependent construct. The percentages of explained variance $\left(\mathrm{R}^{2}\right)$ for the knowledge sharing donation, knowledge sharing collection, and the tech. incubator performance are 0.56, 0.63, and 0.76, respectively. Therefore, the result of the $\mathrm{R}^{2}$ shows a satisfactory level of explanation. In addition, in order to address the predictive relevance of the PLS model, we measured the Stone-Geisser criterion $\mathrm{Q}^{2}$ using the blindfolding method to compute the construct cross-validated redundancy for assessing the predictive relevance (Henseler et al. 2009). In our analysis, $Q^{2}$ values range from the 'technology incubator performance' construct (i.e., 0.31) above the threshold value of zero, thus indicating a strong predictive relevance.

As shown in Table 4, the results confirm the relationship in not significant for hypotheses H1a, H3b, $\mathrm{H} 4 \mathrm{~b}, \mathrm{H} 9, \mathrm{H} 10$, and H11. However, all other hypotheses are accepted at $\mathrm{p}<0.05$. Figure 2 shows the path testing.

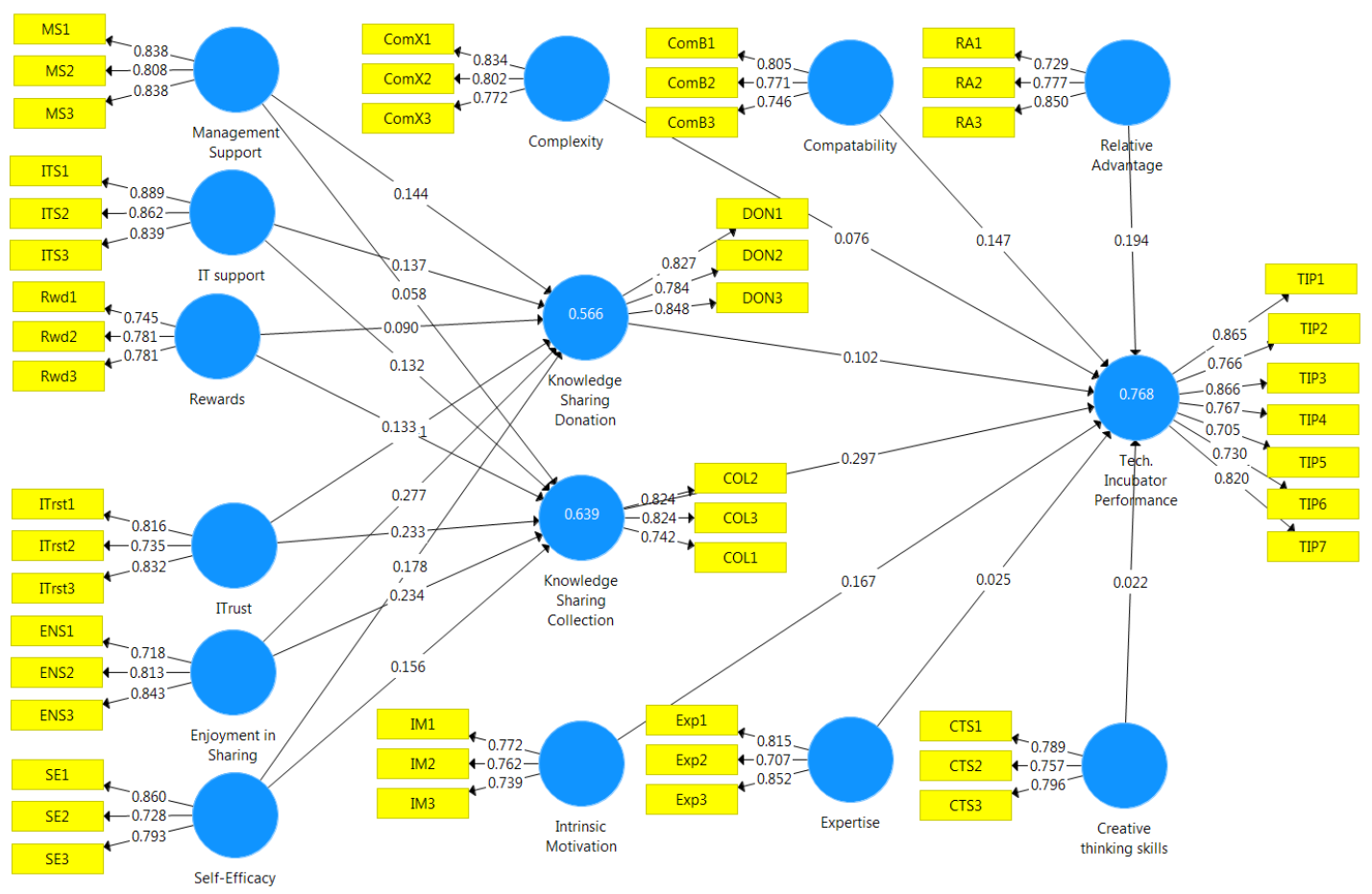


Figure 2. Path Testing

Table 4: Hypotheses Testing

\begin{tabular}{|c|c|c|c|c|c|c|}
\hline & & $\begin{array}{l}\text { Sample } \\
\text { Mean }(M)\end{array}$ & $\begin{array}{l}\text { Standard } \\
\text { Deviation } \\
\text { (STDEV) }\end{array}$ & T Statistics & P Values & Supported? \\
\hline H1a & $\begin{array}{l}\text { Management Support -> Knowledge Sharing } \\
\text { Donation }\end{array}$ & 0.14 & 0.06 & 2.25 & 0.02 & Yes \\
\hline H1b & $\begin{array}{l}\text { Management Support -> Knowledge Sharing } \\
\text { Collection }\end{array}$ & 0.06 & 0.06 & 0.97 & 0.33 & No \\
\hline H2a & IT support -> Knowledge Sharing Donation & 0.13 & 0.06 & 2.28 & 0.02 & Yes \\
\hline H2b & IT support -> Knowledge Sharing Collection & 0.13 & 0.06 & 2.39 & 0.02 & Yes \\
\hline H3a & Rewards -> Knowledge Sharing Donation & 0.10 & 0.08 & 1.18 & 0.24 & No \\
\hline H3b & Rewards -> Knowledge Sharing Collection & 0.14 & 0.06 & 2.14 & 0.03 & Yes \\
\hline H4a & ITrust -> Knowledge Sharing Donation & 0.04 & 0.05 & 0.77 & 0.44 & No \\
\hline H4b & ITrust -> Knowledge Sharing Collection & 0.23 & 0.05 & 5.13 & 0.00 & Yes \\
\hline H5a & $\begin{array}{l}\text { Enjoyment in Sharing -> Knowledge Sharing } \\
\text { Donation }\end{array}$ & 0.28 & 0.07 & 3.98 & 0.00 & Yes \\
\hline H5b & $\begin{array}{l}\text { Enjoyment in Sharing -> Knowledge Sharing } \\
\text { Collection }\end{array}$ & 0.23 & 0.06 & 3.62 & 0.00 & Yes \\
\hline H6a & Self-Efficacy -> Knowledge Sharing Donation & 0.17 & 0.08 & 2.17 & 0.03 & Yes \\
\hline H6b & Self-Efficacy -> Knowledge Sharing Collection & 0.15 & 0.08 & 2.01 & 0.04 & Yes \\
\hline H7a & $\begin{array}{l}\text { Knowledge Sharing Donation -> Tech. Incubator } \\
\text { Performance }\end{array}$ & 0.10 & 0.06 & 1.70 & 0.03 & Yes \\
\hline H7b & $\begin{array}{l}\text { Knowledge Sharing Collection -> Tech. Incubator } \\
\text { Performance }\end{array}$ & 0.30 & 0.06 & 4.92 & 0.00 & Yes \\
\hline H8 & Intrinsic Motivation -> Tech. Incubator Performance & 0.17 & 0.05 & 3.63 & 0.00 & Yes \\
\hline H9 & Expertise -> Tech. Incubator Performance & 0.02 & 0.05 & 0.54 & 0.59 & No \\
\hline H10 & $\begin{array}{l}\text { Creative thinking skills }->\text { Tech. Incubator } \\
\text { Performance }\end{array}$ & 0.03 & 0.04 & 0.62 & 0.53 & No \\
\hline H11 & Complexity -> Tech. Incubator Performance & 0.07 & 0.06 & 1.19 & 0.23 & Yes \\
\hline H12 & Compatability -> Tech. Incubator Performance & 0.14 & 0.05 & 2.84 & 0.00 & Yes \\
\hline $\mathbf{H 1 3}$ & Relative Advantage -> Tech. Incubator Performance & 0.20 & 0.05 & 3.93 & 0.00 & Yes \\
\hline
\end{tabular}

Importance-performance map analysis: We also measure the importance-performance map analysis (IPMA) for generating additional findings and conclusions for managerial actions (Christian and Sarstedt 2016). The IPMA is explained in detail by (Christian and Sarstedt 2016; Hock et al. 2010). Performing an IPMA requires determining a targeting construct, such as knowledge sharing collection, knowledge sharing donation, and technology incubator performance in our PLS path model. The performance of each construct measured on a scale from 0 to 100 . The closer the value to 100 the higher the performance of the variable. 
All total effects (importance) larger than 0.10 are significant at the $\mathrm{p} \leq 0.10$ level. Table 5 - 6 and Figure 3 to 5 shows the IPMA result of the three target constructs (knowledge sharing collection, knowledge sharing donation, and technology incubator performance).

Table 5: IPMA results of knowledge sharing process

\begin{tabular}{|c|c|c|c|}
\hline \multirow[t]{2}{*}{ Latent Variables } & $\begin{array}{l}\text { Criterion: } \\
\text { Knowledge Sharing } \\
\text { Collection }\end{array}$ & $\begin{array}{l}\text { Criterion: } \\
\text { Knowledge Sharing } \\
\text { Donation }\end{array}$ & \multirow[t]{2}{*}{ Performances } \\
\hline & Importance & Importance & \\
\hline Enjoyment in Sharing & 0.31 & 0.17 & 66.25 \\
\hline IT support & 0.11 & 0.02 & 59.92 \\
\hline ITrust & 0.15 & 0.01 & 46.46 \\
\hline Management Support & -0.08 & 0.11 & 65.65 \\
\hline Rewards & 0.27 & 0.05 & 67.89 \\
\hline Self-Efficacy & 0.19 & 0.49 & 61.73 \\
\hline
\end{tabular}

Table 5 presents the IPMA results of the "knowledge sharing collection" and "knowledge sharing donation" target constructs, as illustrated in Figure 3 the highest importance towards "knowledge sharing collection" is "enjoyment in sharing" factor followed by "rewards." This means that the target construct "knowledge sharing collection" would increase by 0.31 total effects of enjoyment in sharing" and 0.27 total effects of "rewards." In a similar way, as shown in Figure 4 the most important factors for the "knowledge sharing donation" target construct are "self-efficacy" followed by "enjoyment in sharing."

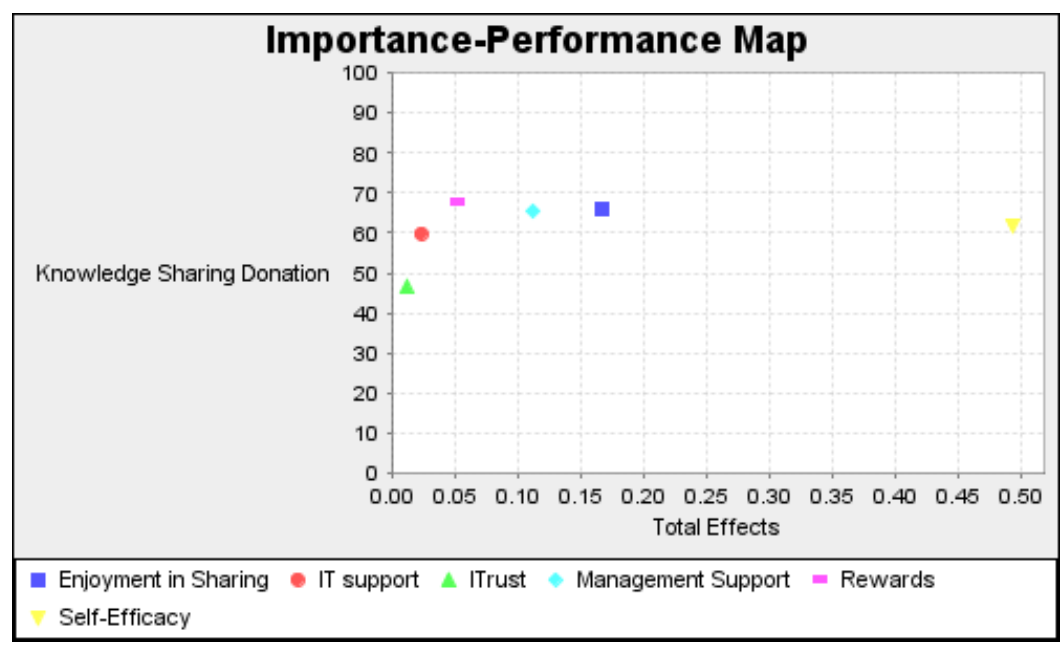

Figure 3. IPMA knowledge sharing donation 


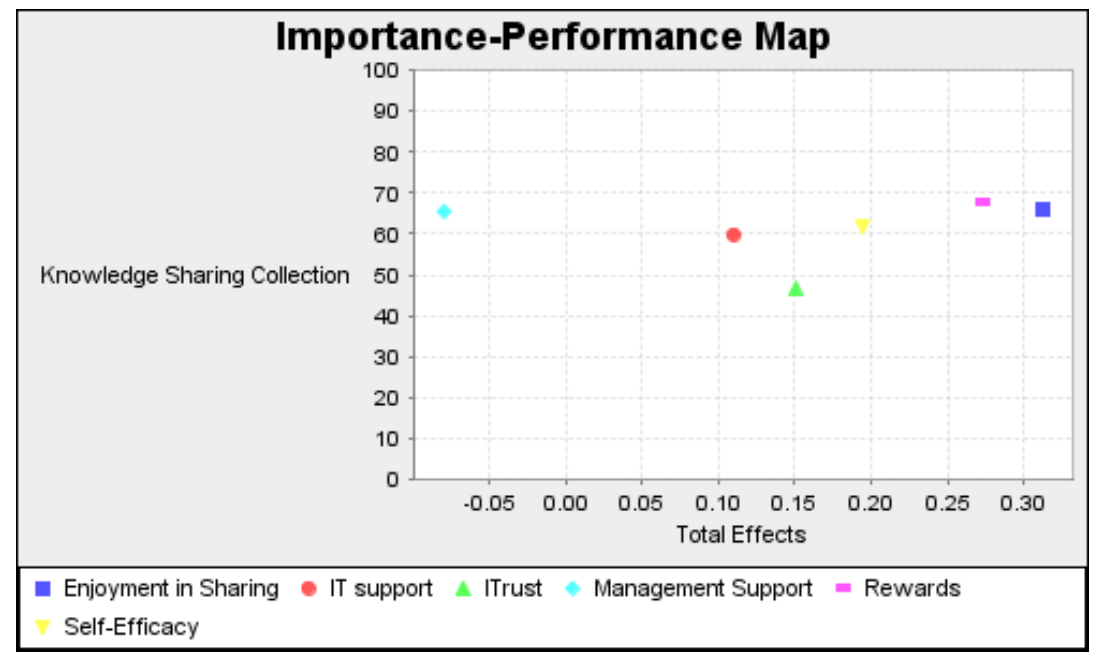

Figure 4. IPMA knowledge sharing collection

Regarding the "technology incubator performance," as presented in Table 6 and Figure 5 the highest performance construct is "relative advantage" followed by "knowledge sharing collection." This means the increase in "relative advantage" performance would increase the performance of the target construct "technology incubator performance" by the size of the total effect. The shows the "technology incubator performance" would increase by a value of 0.28 of "relative advantage" and 0.23 value of "knowledge sharing collection."

Table 6: IPMA results of Tech. business incubator performance

\begin{tabular}{|l|r|r|}
\hline $\begin{array}{l}\text { Criterion: Tech. Business } \\
\text { Incubator Performance }\end{array}$ & Importance & Performance values \\
\hline Expertise & 0.08 & 46.99 \\
\hline Creative thinking skills & 0.05 & 67.53 \\
\hline Intrinsic Motivation & 0.13 & 63.21 \\
\hline $\begin{array}{l}\text { Knowledge Sharing } \\
\text { Collection }\end{array}$ & 0.23 & 57.64 \\
\hline $\begin{array}{l}\text { Knowledge Sharing } \\
\text { Donation }\end{array}$ & 0.06 & 65.44 \\
\hline Relative Advantage & 0.28 & 66.32 \\
\hline Compatibility & 0.14 & 68.47 \\
\hline Complexity & -0.02 & 65.11 \\
\hline $\begin{array}{l}\text { Tech. Incubator } \\
\text { Performance }\end{array}$ & 0.07 & 69.09 \\
\hline
\end{tabular}




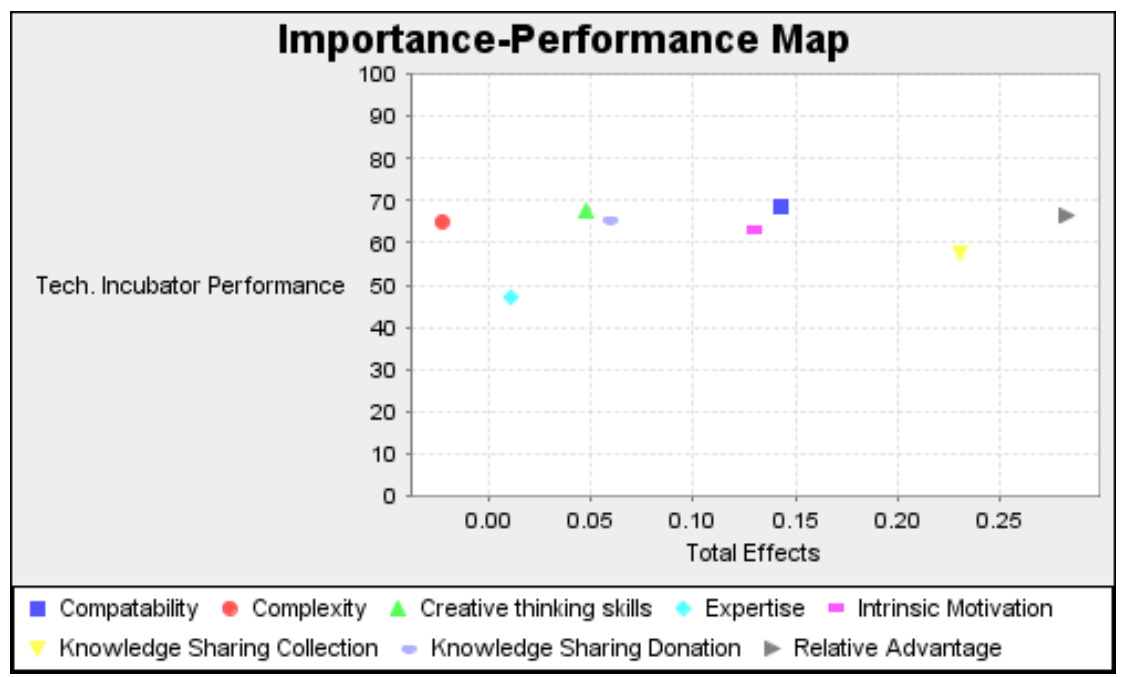

Figure 5. IPMA Tech. business incubator performance

\section{Discussion and Conclusion}

According to the path testing as shown in Figure 2, the order of effects among the knowledge sharing organizational factors that have a significant effect on "knowledge sharing donation" is "management support", and on "knowledge sharing collection" is "rewards". This indicates that giving incentives to employees helps to encourage knowledge-sharing processes. Previous studies resulted that rewards positively influence employees' willing for sharing knowledge (Wang and Noe, 2010, Jolaee et al., 2014). This could be attributed to the fact all the participants in the survey were Muslims. As per Islamic belief, rewards are encouraged by religion which is consistent with Prophet Mohammed's recommendation. Additionally, participants' knowledge-sharing information is influenced by the degree of top management and IT support. This is consistent with (Yew Wong 2005). This is also align with the literature (Gupta and Govindarajan 2000, Othman et al., 2014), which underlines that senior management support is important in knowledge sharing and that employees are influenced by the degree of senior management support.

In addition to this, the order of significance among the knowledge sharing individual factors that have a significant effect on "knowledge sharing donation" is "enjoyment is sharing," on "knowledge sharing collection" are "interpersonal trust" and also "enjoyment is sharing." This shows that employees enjoy helping each and others and having a good level of faith in each other regarding their capabilities to organize and execute courses of action required to achieve specific levels of performance. Finally, knowledge-sharing processes (collection) would enhance technology incubator performance such as tenant firms' survival and growth, contributions to sponsoring universities' missions and community-related impacts (such as sales, revenues, taxes, experience and graduate employment). These findings are consistent with the literature carried on "enjoyment is sharing" (Lin 2007, McLure Wasko and Faraj 2000, Wasko and Faraj 2005) which shows that incubatees enjoy 
helping each other and that plays a significate role in knowledge sharing process in the incubators and "self- efficacy" (Gist and Mitchell 1992, Bandura 1997) which underlines that the individual sense of self-efficacy is affected by tendency of individuals to take actions such as level of problems, expressed interest, persistence and task effort. Moreover, the findings of "interpersonal trust" that shows that incubatees are having a good level of faith in each other regarding their sharing knowledge are compatible with the previous studies (Bijlsma and Koopman 2003, Ma et al., 2008, Davenport and Prusak 1998, Fukuyama 1995).

Creativity and innovation are critical to the success of any organizations (Michael et al. 2012). The complexity of an innovation may have a strong influence on its likelihood of spreading because simple innovations are considerably easier to adopt, while more complex innovations may require external pressure (Zhu 2014). Compatibility is also a natural determinant in that, even if a new approach is clearly better, it will be considerably harder to adopt if it is incompatible with existing approaches and therefore requires significant retooling to implement (Sharp and Miller 2016). Thus, firms will consider compatibility seriously in adopting innovations, especially considering that incompatibility has a significant cost in time and equipment, as well as potentially the related expertise. Finally, relative advantage represents how much of an actual benefit the innovation offers. Even if an innovation is simple and easily compatible, it may not spread easily if firms do not perceive a significant advantage inherent in its adoption compared to existing techniques (Arfken et al. 2015). The results show "intrinsic motivation" and "relative advantage" has the highest effect on "technology business incubator performance." These findings are consisted with the previous studies (Rogers 2003, Autant-Bernard et al. 2013, Arfken et al., 2015).

Creativity, along with knowledge and expertise, is one of the central human resources that can help to achieve the technological commercialization competence (Chen and Schaeffer 2009). As such, the recruitment of knowledgeable, skilled and creative personnel can be integral to the overall performance of incubators. Individual Expertise may contribute to creativity in unexpected ways; team members who exhibit considerable dissimilarity in expertise to other members of their team demonstrate statistically significant increases in individual creativity (Huang et al. 2014). The recruitment of young graduates who have creative and innovative ideas plays in the transfer of technology to industry (Al-Mubaraki et al. 2011).

In conclusion, this study has fulfilled its main aim to examine technology business incubator performance by studying the incubation process, such as the knowledge-sharing process, which is important in the developmental process of new ventures. Figure 2 shows summaries the stakeholder's view in the study analysis. 


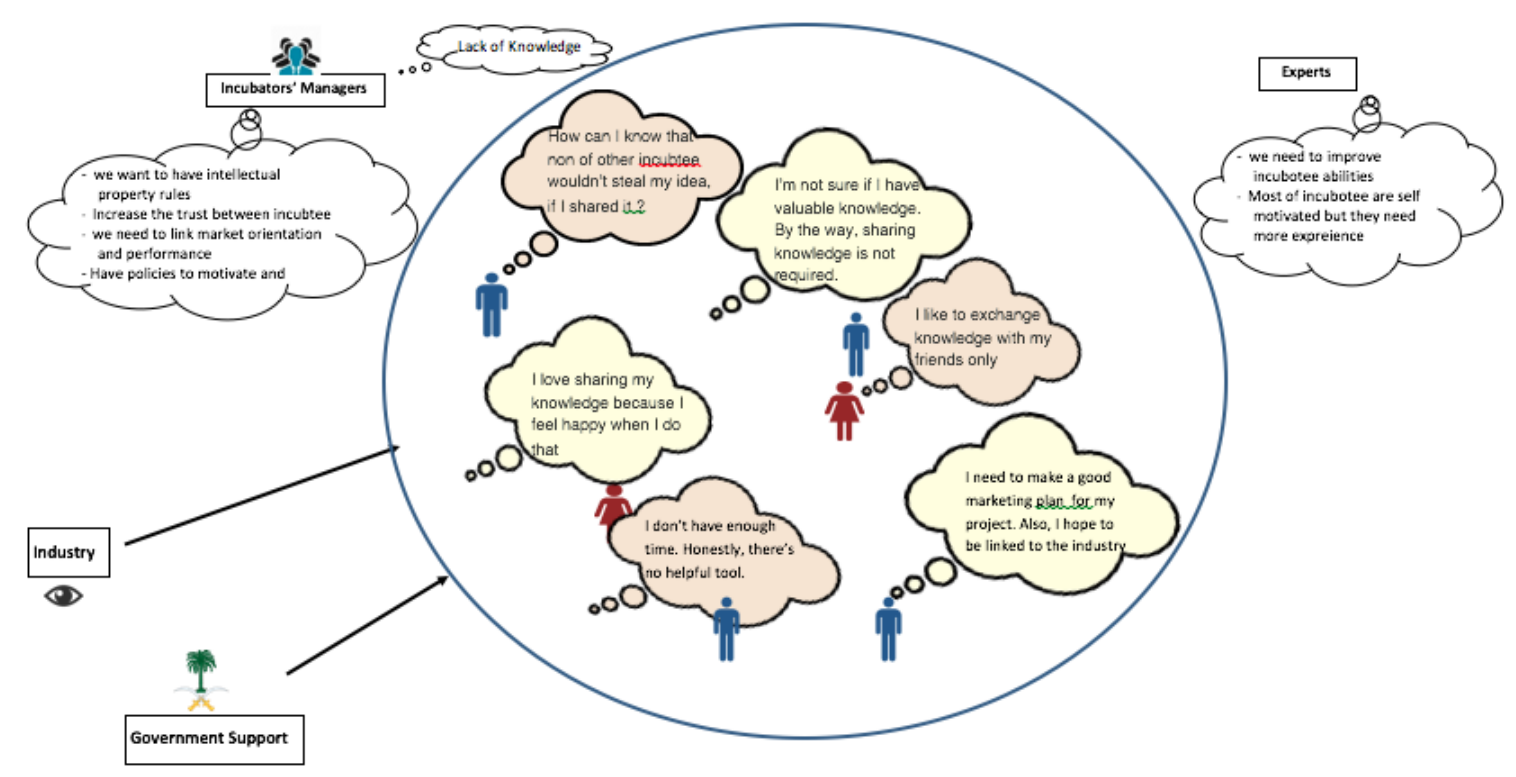

Figure 5. Stakeholder's analysis

\subsection{Implications}

Concerning implications from a theoretical and practical perspective, this study contributes to the literature by presenting a proposed knowledge-sharing factors model in the incubator context. The study advances the understanding of knowledge sharing factors and process, creativity and diffusion of innovation by applying it the technology business incubator context.

Practically, therefore, in an effort to encourage employees to adopt knowledge-sharing processes, Saudi technology incubators should implement supportive knowledge-sharing processes within the organization. As a result, the incubators' stakeholders will gain advantages from knowledge-sharing that will improve the organization's goals achievement. The Saudi incubators are designed for technology innovations, which are mainly established to serve as knowledge-based programs to produce opportunities that lead to transforming the country into a knowledge-based society and consequently developing a knowledge-based economy. The results of this study may help the decision makers in incubators to modify their strategy, and increase the outcome of their organisations by focusing on the knowledge sharing factors, innovation and creativity.

\subsection{Limitations}

Finally, this study has limitations. First, the number of samples is not large enough, and the data were collected in Saudi Arabia only. Therefore the generalizability of the findings may be limited. Second, the study did not consider all possible factors that could impact technology business incubator. This research model did not cover all aspects of knowledge sharing process. Finally, the broader use of the 
SEM method in future studies will extend the results presentation and allow more elaborate findings and conclusions.

\section{References}

Amabile, T. M. 1988. "A Model of Creativity and Innovation in Organizations," Research in organizational behavior (10:1), pp. 123-167.

Amabile, T. M. 1997. "Motivating Creativity in Organizations: On Doing What You Love and Loving What You Do," California Management Review (40:1), pp. 39-58.

Amabile, T. M., Barsade, S. G., Mueller, J. S., and Staw, B. M. 2005. "Affect and Creativity at Work," Administrative Science Quarterly (50:3), pp. 367-403.

Al-Mubaraki, H., Al-Karaghouli, W. \& Busler, M. 2010, 'The creation of business incubators in supporting economic developments', European, Mediterranean \& Middle Eastern Conference on Information Systems, pp. 12-13.

Ardichvili, A., Page, V., and Wentling, T. 2003. "Motivation and Barriers to Participation in Virtual KnowledgeSharing Communities of Practice," Journal of knowledge management (7:1), pp. 64-77.

Arfken, C. L., Madeja, C., and Owens, D. 2015. "Comparison of Synthetic Substances: Diffusion of Innovation Framework," Drug \& Alcohol Dependence (146), pp. e209-e210.

Artail, H. A. 2006. "Application of Km Measures to the Impact of a Specialized Groupware System on Corporate Productivity and Operations," Information \& Management (43:4), pp. 551-564.

Ascigil, S. F., and Magner, N. R. 2009. "Business Incubators: Leveraging Skill Utilization through Social Capital," Journal of Small Business Strategy (20:1), p. 19.

Autant-Bernand, C., Fadairo, M. \& Massard, N. 2013. Knowledge diffusion and innovation policies within the European regions: Challenges based on recent empirical evidence. Research Policy, 42, 196-210.

Babbie, E. R. 2013. The basics of social research, Cengage Learning.

Bandura, A. 1997. Self-Efficacy: The Exercise of Control. Macmillan.

Bartol, K. M., and Srivastava, A. 2002. "Encouraging Knowledge Sharing: The Role of Organizational Reward Systems," Journal of Leadership \&amp; Organizational Studies (9:1), pp. 64-76.

Bijlsma, K., and Koopman, P. 2003. "Introduction: Trust within Organisations," Personnel Review (32:5), pp. 543-555.

Binsawad, M., Sohaib, O. and Hawryszkiewycz, I. 2017, "Knowledge Sharing in Technology Business Incubators:", ISD2017 Proceedings, 26th International Conference on Information Systems Development, AIS, Cyprus

Bock, G.-W., and Kim, Y.-G. 2001. "Breaking the Myths of Rewards: An Exploratory Study of Attitudes About Knowledge Sharing," Pacis 2001 proceedings), p. 78.

Bollingtoft, A. and Ulhoi, J. P. 2005. The networked business incubator-leveraging entrepreneurial agency? Journal of business venturing, 20, 265-290.

Brush, C. G., and Greene, P. G. 1996. "Resources in the New Venture Creation Process: Strategies for Acquisition," Academy of Management, Cincinnati, $\mathrm{OH}$ ).

Carlson, C. R., and Wilmot, W. W. 2006. Innovation: The Five Disciplines for Creating What Customers Want. Crown Business.

Chan, K., and Lau, T. 2005. "Assessing Technology Incubator Programs in the Science Park: The Good, the Bad and the Ugly," Technovation (25:10), pp. 1215-1228.

Cheng, S., and Schaeffer, P. V. 2011. "Evaluation without Bias: A Methodological Perspective on Performance Measures for Business Incubators," Region et Developement (33), pp. 211-225.

Christian, M. R., and Sarstedt, M. 2016. "Gain More Insight from Your Pls-Sem Results: The ImportancePerformance Map Analysis," Industrial Management \& Data Systems (116:9), pp. 1865-1886.

Connelly, C. E., and Kevin Kelloway, E. 2003. "Predictors of Employees' Perceptions of Knowledge Sharing Cultures," Leadership \& Organization Development Journal (24:5), pp. 294-301.

Davenport, T. H., and Prusak, L. 1998. Working Knowledge: How Organizations Manage What They Know. Harvard Business Press.

De Vries, R. E., Van den Hooff, B., and de Ridder, J. A. 2006. "Explaining Knowledge Sharing: The Role of Team Communication Styles, Job Satisfaction, and Performance Beliefs," Communication research (33:2), pp. 115-135.

Egbetokun, A., Siyanbola, W., and Adeniyi, A. 2007. "Assessment of Innovation Capability in the Cable and Wire Manufacturing Industry in Nigeria: A Case Study Approach," Micro Evidence on Innovation in developing Economies [MEIDE], May). 
Erickson, G. S., Rothberg, H., and Carr, C. 2003. "Knowledge-Sharing in Value-Chain Networks: Certifying Collaborators for Effective Protection Process,").

Fornell, C., and Larcker, D. F. 1981. "Evaluating Structural Equation Models with Unobservable Variables and Measurement Error," Journal of Marketing Research (18:1), pp. 39-50.

Fukuyama, F. 1995. Trust: The Social Virtues and the Creation of Prosperity. Free Press Paperbacks.

George, J. M., and Zhou, J. 2002. "Understanding When Bad Moods Foster Creativity and Good Ones Don't: The Role of Context and Clarity of Feelings," Journal of Applied Psychology (87:4), pp. 687-697.

Gist, M. E. 1987. "Self-Efficacy: Implications for Organizational Behavior and Human Resource Management," Academy of Management Review (12:3), pp. 472-485.

Grewal, D., Levy, M., and Kumar, V. 2009. "Customer Experience Management in Retailing: An Organizing Framework," Journal of Retailing (85:1), pp. 1-14.

Gupta, A. K., and Govindarajan, V. 2000. "Knowledge Management's Social Dimension: Lessons from Nucor Steel," MIT Sloan Management Review (42:1), p. 71.

Hair, J. F., Ringle, C. M., and Sarstedt, M. 2011a. "Pls-Sem: Indeed a Silver Bullet," Journal of Marketing theory and Practice (19:2), pp. 139-152.

Hair, J. F., Ringle, C. M., and Sarstedt, M. 2011b. "Pls-Sem: Indeed a Silver Bullet," Journal of Marketing Theory and Practice, (19:2), pp. 139-151.

Hair, J. F., Sarstedt, M., Hopkins, L., and Kuppelwieser, V. 2014. Partial Least Squares Structural Equation Modeling (Pls-Sem): An Emerging Tool for Business Research.

Han, B. M., and Anantatmula, V. S. 2007. "Knowledge Sharing in Large It Organizations: A Case Study," VINE (37:4), pp. 421-439.

Henseler, J., Dijkstra, T. K., Sarstedt, M., Ringle, C. M., Diamantopoulos, A., Straub, D. W., David J. Ketchen, J., Hair, J. F., Hult, G. T. M., and Calantone, R. J. 2014. "Common Beliefs and Reality About Pls," Organizational Research Methods (17:2), pp. 182-209.

Henseler, J., Ringle, C. M., and Sinkovics, R. R. 2009. "The Use of Partial Least Squares Path Modeling in International Marketing," New Challenges to International Marketing (Advances in International Marketing) (20), pp. 277 - 319.

Henseler, J., and Sarstedt, M. 2013. "Goodness-of-Fit Indices for Partial Least Squares Path Modeling," Computational Statistics (28:2), pp. 565-580.

Hock, C., Ringle, C., and Sarstedt, M. 2010. Management of Multi-Purpose Stadiums: Importance and Performance Measurement of Service Interfaces.

Hsu, I. C. 2008. "Knowledge Sharing Practices as a Facilitating Factor for Improving Organizational Performance through Human Capital: A Preliminary Test," Expert Systems with Applications (35:3), pp. 1316-1326.

Hughes, M., Ireland, R. D., and Morgan, R. E. 2007. "Stimulating Dynamic Value: Social Capital and Business Incubation as a Pathway to Competitive Success," Long Range Planning (40:2), pp. 154-177.

Huang, X., Hsieh, J., and He, W. 2014. "Expertise Dissimilarity and Creativity: The Contingent Roles of Tacit and Explicit Knowledge Sharing," Journal of Applied Psychology (99:5), p. 816.

JOLAEE, A., MD NOR, K., KHANI, N. \& MD YUSOFF, R. 2014. Factors affecting knowledge sharing intention among academic staff. International Journal of Educational Management, 28, 413-431.

Kharabsheh, R. A. 2007. "A Model of Antecedents of Knowledge Sharing," Electronic Journal of Knowledge Management (5:4), pp. 419-426.

Khorsheed, M. S., Alhargan, A., and Qasim, S. M. 2012. "A Three-Tier Service Model for National Ict Incubator in Saudi Arabia," Proceedings of IEEE International Conference on Management and Service Science, pp. 1-6.

Lee, H., and Choi, B. 2003. "Knowledge Management Enablers, Processes, and Organizational Performance: An Integrative View and Empirical Examination," Journal of management information systems (20:1), pp. 179-228.

Lin, H. F. 2007. "Knowledge Sharing and Firm Innovation Capability: An Empirical Study," International Journal of Manpower (28:3/4), pp. 315-332.

M'Chirgui, Z. 2012. "Assessing the Performance of Business Incubators: Recent France Evidence," Business and Management Research (1:1).

Ma, Z., Qi, L., and Wang, K. 2008. "Knowledge Sharing in Chinese Construction Project Teams and Its Affecting Factors," Chinese Management Studies (2:2), pp. 97-108.

McLure Wasko, M., and Faraj, S. 2000. "“It Is What One Does": Why People Participate and Help Others in Electronic Communities of Practice," The Journal of Strategic Information Systems (9:2-3), pp. 155173.

Mian, S. 2016. "Business Incubation and Incubator Mechanisms," in Technology Entrepreneurship and Business Incubation: Theory• Practice $\bullet$ Lessons Learned. pp. 1-33. 
Mian, S. A. 1996. "Assessing Value-Added Contributions of University Technology Business Incubators to Tenant Firms," Research Policy (25:3), pp. 325-335.

Mian, S. A. 1997. "Assessing and Managing the University Technology Business Incubator: An Integrative Framework," Journal of Business Venturing (12:4), pp. 251-285.

Nold, H. A. 2012. "Linking Knowledge Processes with Firm Performance: Organizational Culture," Journal of Intellectual Capital (13:1), pp. 16-38.

Oldham, G. R., and Cummings, A. 1996. "Employee Creativity: Personal and Contextual Factors at Work," Academy of Management Journal (39:3), pp. 607-634.

OTHMAN, F., HAWRYSZKIEWYCZ, I. \& KANG, K. The Influence of Socio-technical Factors on Knowledge-based Innovation in Saudi Arabia Firms. 2014. ACIS.

Panuwatwanich, K., Stewart, R., and Mohamed, S. 2008. "Empirical Study on the Relationships between Climate for Innovation and Business Performance Outcomes in Design Firms," Proceedings of the Eighth International Post-graduate Research Conference on the Built \& Hu man Environment, Prague (Czech): Czech Technical University, CTU Publishing House.

Park, N. K., Chun, M. Y., and Lee, J. 2016. "Revisiting Individual Creativity Assessment: Triangulation in Subjective and Objective Assessment Methods," Creativity Research Journal (28:1), pp. 1-10.

Patton, D. 2014. "Realising Potential: The Impact of Business Incubation on the Absorptive Capacity of New Technology-Based Firms," International Small Business Journal (32:8), pp. 897-917.

Peters, L., Rice, M., and Sundararajan, M. 2004. "The Role of Incubators in the Entrepreneurial Process," The Journal of Technology Transfer (29:1), pp. 83-91.

Phan, P. H., Siegel, D. S., and Wright, M. 2005. "Science Parks and Incubators: Observations, Synthesis and Future Research," Journal of Business Venturing (20:2), pp. 165-182.

Rahab, S. 2011. "Sudjono,"the Development of Innovation Capability of Small Medium Enterprises through Knowledge Sharing Process: An Empirical Study of Indonesian Creative Industry," International Journal of Business and Social Science (2:21).

Riege, A. 2005. "Three-Dozen Knowledge-Sharing Barriers Managers Must Consider," Journal of Knowledge Management (9:3), pp. 18-35.

Ringle, C. M., Wende, S., and Becker, J.-M. 2015. "Smartpls 3. Hamburg: Smartpls." 2014, from http://www.smartpls.com

ROGERS, E. M. 2003. Elements of diffusion. Diffusion of innovations

Rooney, D., Hearn, G., and Kastelle, T. 2012. "Knowledge Is People Doing Things, Knowledge Economies Are People Doing Things with Better Outcomes for More People," Handbook on the knowledge economy, volume two. Edward Elgar, Cheltenham and Northampton), pp. 1-14.

Rothaermel, F. T., and Thursby, M. 2005. "Incubator Firm Failure or Graduation?: The Role of University Linkages," Research policy (34:7), pp. 1076-1090.

Salem, M. I. 2014. "The Role of Business Incubators in the Economic Development of Saudi Arabia," International Business \& Economics Research Journal (IBER) (13:4), p. 853.

Sarstedt, M., Hair, J. F., Ringle, C. M., Thiele, K. O., and Gudergan, S. P. 2016. "Estimation Issues with Pls and Cbsem: Where the Bias Lies!," Journal of Business Research (69:10), pp. 3998-4010.

SHARP, B. E. \& MILLER, S. A. 2016. Potential for Integrating Diffusion of Innovation Principles into Life Cycle Assessment of Emerging Technologies. Environmental science \& technology, 50, 2771-2781.

Smilor, R. W. 1987. "Commercializing Technology through New Business Incubators," Research Management (30:5), pp. 36-41.

Somsuk, N., and Laosirihongthong, T. 2014. "A Fuzzy Ahp to Prioritize Enabling Factors for Strategic Management of University Business Incubators: Resource-Based View," Technological Forecasting and Social Change (85), pp. 198-210.

Song, D. 2009. "The Tacit Knowledge-Sharing Strategy Analysis in the Project Work," International Business Research (2:1).

Tamasy, C. 2007. "Rethinking Technology-Oriented Business Incubators: Developing a Robust Policy Instrument for Entrepreneurship, Innovation, and Regional Development?," Growth and Change (38:3), pp. 460-473.

Tang, M., Baskaran, A., Pancholi, J., and Lu, Y. 2013. "Technology Business Incubators in China and India: A Comparative Analysis," Journal of Global Information Technology Management (16:2), pp. 33-58.

Taylor, M. S., Grossman, G. M., and Helpman, E. 1993. "Innovation and Growth in the Global Economy," Economica (60:239), p. 373.

Tötterman, H., and Sten, J. 2005. "Start-Ups: Business Incubation and Social Capital," International small business journal (23:5), pp. 487-511.

Udell, G. G. 1990. "Academe and the Goose That Lays Its Golden Egg," Business Horizons (33:2), pp. 29-37. 
Van den Hooff, B., and de Leeuw van Weenen, F. 2004. "Committed to Share: Commitment and Cmc Use as Antecedents of Knowledge Sharing," Knowledge and process management (11:1), pp. 13-24.

Van Den Hooff, B., and De Ridder, J. A. 2004. "Knowledge Sharing in Context: The Influence of Organizational Commitment, Communication Climate and Cmc Use on Knowledge Sharing," Journal of knowledge management (8:6), pp. 117-130.

Wang, Z., and Wang, N. 2012. "Knowledge Sharing, Innovation and Firm Performance," Expert Systems with Applications (39:10), pp. 8899-8908.

Wasko, M. M., and Faraj, S. 2005. "Why Should I Share? Examining Social Capital and Knowledge Contribution in Electronic Networks of Practice," MIS quarterly), pp. 35-57.

West, G. P., and Noel, T. W. 2009. "The Impact of Knowledge Resources on New Venture Performance," Journal of Small Business Management (47:1), pp. 1-22.

Wiklund, J. \& Shepherd, D. 2003. Knowledge - based resources, entrepreneurial orientation, and the performance of small and medium - sized businesses. Strategic management journal, 24, 1307-1314.

Wonglimpiyarat, J. 2016. "The Innovation Incubator, University Business Incubator and Technology Transfer Strategy: The Case of Thailand," Technology in Society (46), pp. 18-27.

Woodman, R. W., Sawyer, J. E., and Griffin, R. W. 1993a. "Toward a Theory of Organizational Creativity," The Academy of Management Review (18:2), p. 293.

Woodman, R. W., Sawyer, J. E., and Griffin, R. W. 1993b. "Toward a Theory of Organizational Creativity," Academy of Management Review (18:2), pp. 293-321.

Yee, N. G. 2009. "Technology Incubator Performance in New Zealand," in: 2009 International Conference on Innovation Management. IEEE.

Yew Wong, K. 2005. "Critical Success Factors for Implementing Knowledge Management in Small and Medium Enterprises," Industrial Management \& Data Systems (105:3), pp. 261-279.

Zhu, X. 2014. "Mandate Versus Championship: Vertical Government Intervention and Diffusion of Innovation in Public Services in Authoritarian China," Public Management Review (16:1), pp. 117-139.

Zhu, X., and Zhang, Y. 2015. "Political Mobility and Dynamic Diffusion of Innovation: The Spread of Municipal Pro-Business Administrative Reform in China," Journal of Public Administration Research and Theory (26:3), pp. 535-551. 


\begin{tabular}{|c|c|c|}
\hline \multicolumn{2}{|c|}{ Appendix A: Questionnaire. } & \\
\hline & Management Support (MS) & \multirow{12}{*}{$\begin{array}{l}\text { (Lin 2007; Van } \\
\text { den Hooff and de } \\
\text { Leeuw van } \\
\text { Weenen 2004) }\end{array}$} \\
\hline 1 & $\begin{array}{l}\text { The top management provides with necessary resources and environment for } \\
\text { motivating employees. }\end{array}$ & \\
\hline 2 & $\begin{array}{l}\text { The top management of technology business incubator keeps a two-way } \\
\text { communication system always open for encouraging weak performers. }\end{array}$ & \\
\hline \multirow[t]{2}{*}{3} & $\begin{array}{l}\text { The top management of technology business incubator takes motivational } \\
\text { initiatives such as appreciation of good performance and knowledge sharing } \\
\text { activities. }\end{array}$ & \\
\hline & IT Support (ITS) & \\
\hline 1 & $\begin{array}{l}\text { The technology business incubator facilitates me with appropriate technical } \\
\text { tools required for knowledge sharing. }\end{array}$ & \\
\hline 2 & $\begin{array}{l}\text { My co-workers utilize electronic data management system for accessing and } \\
\text { storing the recent information. }\end{array}$ & \\
\hline \multirow[t]{2}{*}{3} & $\begin{array}{l}\text { The advanced technological tools that are available in technology business } \\
\text { incubator promote knowledge sharing }\end{array}$ & \\
\hline & Reward (RWD) & \\
\hline 1 & $\begin{array}{l}\text { The top management financially rewards the employees for knowledge } \\
\text { sharing initiatives in technology business incubator. }\end{array}$ & \\
\hline 2 & Rewards for knowledge sharing contribute to motivating the employees. & \\
\hline \multirow[t]{2}{*}{3} & $\begin{array}{l}\text { The top management adopts non-monetary measures for rewarding the } \\
\text { employees that share their experiences and knowledge. }\end{array}$ & \\
\hline & Self-Efficacy (OIC) & \multirow{12}{*}{$\begin{array}{l}\text { (Lin, 2007; } \\
\text { (Whitener 2001, } \\
\text { Politis 2003). }\end{array}$} \\
\hline 1 & My individual performance represents the level of self-efficacy. & \\
\hline 2 & $\begin{array}{l}\text { My focus on the development of skills has a direct impact on my level of } \\
\text { self-efficacy }\end{array}$ & \\
\hline \multirow[t]{2}{*}{3} & Self-efficacy plays an important role in efficient sharing of knowledge. & \\
\hline & Interpersonal Trust (IPT) & \\
\hline 1 & $\begin{array}{l}\text { I don't hesitate to share my feelings and point of views with my colleagues } \\
\text { at the workplace }\end{array}$ & \\
\hline 2 & I believe that staff should not share personal information at the workplace. & \\
\hline \multirow[t]{2}{*}{3} & In our Incubator a considerable level of trust exists among colleagues. & \\
\hline & Enjoyment in Sharing (ENS) & \\
\hline 1 & My colleagues love sharing their knowledge with other workers. & \\
\hline 2 & I enjoy helping colleagues by sharing my knowledge & \\
\hline \multirow[t]{2}{*}{3} & Sharing my knowledge with colleagues is pleasurable & \\
\hline & $\begin{array}{l}\text { Knowledge Sharing Process (KSP) } \\
\text { (Donation and Collection) }\end{array}$ & \multirow[t]{2}{*}{$\begin{array}{l}\text { (Van Den Hooff } \\
\text { and } \\
\text { Weenan, 2004; } \\
\text { Lin, 2007). }\end{array}$} \\
\hline DON1 & I often share with my colleagues the new skills I learn with my colleagues & \\
\hline
\end{tabular}




\begin{tabular}{|c|c|c|}
\hline DON2 & When I have learned something new, I tell my colleagues about it & \\
\hline DON3 & I share information I have with colleagues when they ask for it & \\
\hline COL1 & Knowledge sharing among colleagues is considered normal in my company. & \\
\hline COL2 & $\begin{array}{l}\text { Knowledge sharing practices undertaken within organization leads to } \\
\text { enhance the Incubator performance }\end{array}$ & \\
\hline COL3 & $\begin{array}{l}\text { Knowledge sharing is considered as normal and appreciable practice in } \\
\text { technology incubator. }\end{array}$ & \\
\hline & $\begin{array}{l}\text { Diffusion of Innovation (DOI) } \\
\text { Complexity (ComX) }\end{array}$ & \multirow{12}{*}{$\begin{array}{lrr}\text { Roger, } & \text { 2003; } \\
\text { Othman } & \text { et al. } \\
2014) & \\
\text { Rogers } & \text { (2010); } \\
\text { Fennell r and } & \text { Warnecke } \\
\text { (2013); } & \text { Seemann } \\
(2003) ; & \text { Sahin } \\
(2006) & \end{array}$} \\
\hline 1 & $\begin{array}{l}\text { Complexity feature of innovation hinders the diffusion of technology in the } \\
\text { technology business incubator. }\end{array}$ & \\
\hline 2 & $\begin{array}{l}\text { The sharing of ideas and mutual discussions can reduce the complexity of } \\
\text { innovation diffusion in the technology business incubator. }\end{array}$ & \\
\hline \multirow[t]{2}{*}{3} & $\begin{array}{l}\text { In the technology business incubator, innovation complexities are resolved } \\
\text { by educating employees about the foundation of developed innovation. }\end{array}$ & \\
\hline & Compatibility (ComB) & \\
\hline 1 & $\begin{array}{l}\text { I think compatibility of innovation with the current values and practices of } \\
\text { the technology business incubator are necessary. }\end{array}$ & \\
\hline 2 & Our innovation is compatible with our social values. & \\
\hline \multirow[t]{2}{*}{3} & Our research is compatible with university research. & \\
\hline & Relative Advantage (RelA) & \\
\hline 1 & My co-workers perceive innovation as advantageous. & \\
\hline 2 & $\begin{array}{l}\text { Relative advantage of innovation plays a crucial role in persuading people } \\
\text { for innovation adoption. }\end{array}$ & \\
\hline \multirow[t]{2}{*}{3} & $\begin{array}{l}\text { Our innovation largely determines the specific type of relative advantage } \\
\text { (such as economic, social. }\end{array}$ & \\
\hline & $\begin{array}{l}\text { Creativity } \\
\text { Intrinsic Motivation (IMoT) }\end{array}$ & \multirow{12}{*}{$\begin{array}{l}\text { (Amabile 1988; } \\
\text { Amabile 1997; } \\
\text { Amabile et al. } \\
\text { 2005) }\end{array}$} \\
\hline 1 & We have a useful of resources to work effectively. & \\
\hline 2 & I am affected by the work environment to be engaged in the creative process. & \\
\hline \multirow[t]{2}{*}{3} & I enjoy challenging in my work. & \\
\hline & Expertise (Exp) & \\
\hline 1 & I know what our organisation wants to achieve. & \\
\hline 2 & I have the acquired expertise in particular field. & \\
\hline \multirow[t]{2}{*}{3} & I can solve complex problems. & \\
\hline & Creative Thinking Skills (CTS) & \\
\hline 1 & I am good at generating novel ideas. & \\
\hline 2 & I have the acquired training for idea generation. & \\
\hline \multirow[t]{2}{*}{3} & Brainstorming sessions help me to connect ideas generation into solution. & \\
\hline & Technology Business Incubators Performance & \multirow{2}{*}{$\begin{array}{l}\text { (Mian 1996; } \\
\text { Mian 1997) }\end{array}$} \\
\hline 1 & $\begin{array}{l}\text { Please assess Incubator firm performance compared to other firms facing } \\
\text { similar development challenges or that are in the same business on a scale } \\
\text { ranging from 'very low performer' (1) to 'very high performer' (5), in the }\end{array}$ & \\
\hline
\end{tabular}




\begin{tabular}{|l|l|}
\hline & following areas: \\
\hline $\mathbf{2}$ & $\begin{array}{l}\text { Program profile (growth in budget, space, facilities, services, tenants and } \\
\text { staff). }\end{array}$ \\
\hline $\mathbf{3}$ & Presence of a complementing research park facility. \\
\hline $\mathbf{4}$ & $\begin{array}{l}\text { Level of funding received from key donors including state, industry, } \\
\text { university }\end{array}$ \\
\hline $\mathbf{5}$ & Tenant firms' survivability (ratio of survivors to discontinuances) \\
\hline $\mathbf{6}$ & Tenant firms' employment growth (\% annual growth during incubation) \\
\hline $\mathbf{7}$ & Impact on university's teaching and research \\
\hline $\mathbf{8}$ & Students/graduates hired by tenants as employees. \\
\hline
\end{tabular}

